\title{
Between men and women
}

\section{Robert Attenborough}

The Descent of Woman: A New Edition. By Elaine Morgan.

Souvenir Press: 1985. Pp.288. Hbk£8.95; pbk £5.95.

Myths of Gender: Biological Theories About Women and Men.

By Anne Fausto-Sterling. Basic Books: 1986. Pp.258. \$18.95.

THERE are some books which a male reviewer takes on at his peril. These two come into that category. Both authors are female and feminist, and both write about human evolution and biology with a particular interest in the female side (or, to put it more even-handedly, in sex and gender). But there, on the whole, the resemblances end. Elaine Morgan is a Welsh freelance writer, and her speculative evolutionary history, of woman as well as man, dates back to 1972 . Anne Fausto-Sterling is an American academic (a developmental geneticist), and her new book surveys a series of controversies about the biology of sex differences and roles.

Elaine Morgan's publishers puff up her book as "the classic study of evolution - a new edition". Certainly it was enjoyed by many, was welcomed as a breath of fresh air by feminists and was found stimulating by at least some evolutionary biologists. If the books of Robert Ardrey, Konrad Lorenz and Desmond Morris (in order of chronology, not merit) represented the first generation of the speculative human ethology which began in the 1960 s, Elaine Morgan's belonged to the second. She had read the earlier books, and to some extent the academic literature beyond them, and wrote a riposte in a similar style giving her version of the human evolutionary scenario in the manner that Stephen Gould calls "adaptive storytelling". Her particular theme was a dual one: that evolutionary views of "man the hunter" and so on were too male-centred, not just in using "man" and "he" for the species but in paying too little attention to female roles and selection pressures; and that a better scenario for human evolution could be based on the "aquatic ape" hypothesis - the idea, proposed by Sir Alister Hardy and outlined to a wider public by Desmond Morris, that there was an aquatic (perhaps better, littoral) phase in human evolution during the Pliocene which influenced our adaptations then and since.

Morgan wrote with an engaging panache, and while not all her arguments and criticisms hit their target effectively, some certainly did. That she was right to focus more attention on the female part in human evolution is clear, and other books such as Nancy Tanner's On Becoming Human (Cambridge University Press, 1981) and Sarah Hrdy's The Woman That
Never Evolved (Harvard University Press, 1981) have since made the same point in different and more scholarly ways. Not so many authors have followed Morgan in the aquatic hypothesis, but she herself wrote a second book, The Aquatic Ape (Souvenir Press, 1982), designed, with some success, to win from academics a more serious hearing for the idea. In both its main themes, then, The Descent of Woman is now largely superseded. In not revising the book beyond deleting one chapter and adding a 15-page postscript, Elaine Morgan herself seems to admit to a view of the book as more a period piece than an essay to be taken at face value today for its substantive content.

By contrast, Myths of Gender certainly does ask, and deserve, to be taken seriously. Rather than tracing an evolutionary sequence or developing a cumulative argument, Anne Fausto-Sterling devotes the core of her book to examining a set of controversial propositions which have in common simply that they attribute some aspect of females, males or the differences between them to biology. Principally, these propositions concern intellectual differences between the sexes; the development of sex roles in society; the behavioural impact of female hormones in menstruation and menopause; the relationship between male hormones and aggression; and evolutionary (especially sociobiological, needless to say) theories of the behaviour and relationships of the sexes. These are the "myths" of the title, and although that does not strictly imply that they are untrue, the burden of the book is that the propositions in question need sceptical examination, and are often wrong or unsubstantiated.

Fausto-Sterling makes this argument in each case in a way that is in some respects conventionally academic. She herself says that in this politically sensitive area she applies especially high scientific standards, but that is not just an excuse to dismiss unpalatable findings: on the contrary, the book is closely and intelligently argued, well documented factually and carefully referenced (albeit by the irritating end-note method). There are, throughout, interpretations one might argue with, and on occasion there are factual errors (for example that "humans are the only primates exhibiting handedness or hemispheric specialization"). Perhaps, too, the coverage would have been strengthened by greater input from the social sciences.

For whom the book is intended is not entirely evident. Fausto-Sterling can write quite well and clearly, and the book demands little prior knowledge. In some ways, it reads as if designed for a first-year undergraduate audience, perhaps even as
TO CRYSTALLIZATION

$$
\begin{gathered}
\text { The atom is a crystal } \\
\text { of a sort; the lattices } \\
\text { its interlockings form } \\
\text { lend a planarity most pleasing } \\
\text { to the abysses and cliffs, much magnified, } \\
\text { of (for example) salt and tourmaline. } \\
\text { Arise, order, } \\
\text { out of necessity! } \\
\text { Mock, you crystals, } \\
\text { with all appearance of chiselled design, } \\
\text { our hope of a Grand Artificer. } \\
\text { The graceful layered frost-ferns the midnight elves } \\
\text { left on the Shillington windowpanes } \\
\text { for my morning astonishment were misinformation, } \\
\text { as is } \\
\text { the glittering explosion of tinted quartz } \\
\text { discovered in earth like a heart of thought, } \\
\text { buried evidence } \\
\text { crying out for release to the workman's pick, } \\
\text { tangled hexagonal hair of an angel interred } \\
\text { where it fell, our earth still molten, in the Fall. } \\
\text { When, on those anvils at the center of stars } \\
\text { and those even more furious anvils } \\
\text { of the exploding supernovae, } \\
\text { the heavy elements were beaten together } \\
\text { to the atomic number of } 94 \\
\text { and the crystalline metals with their easily lost }
\end{gathered}
$$

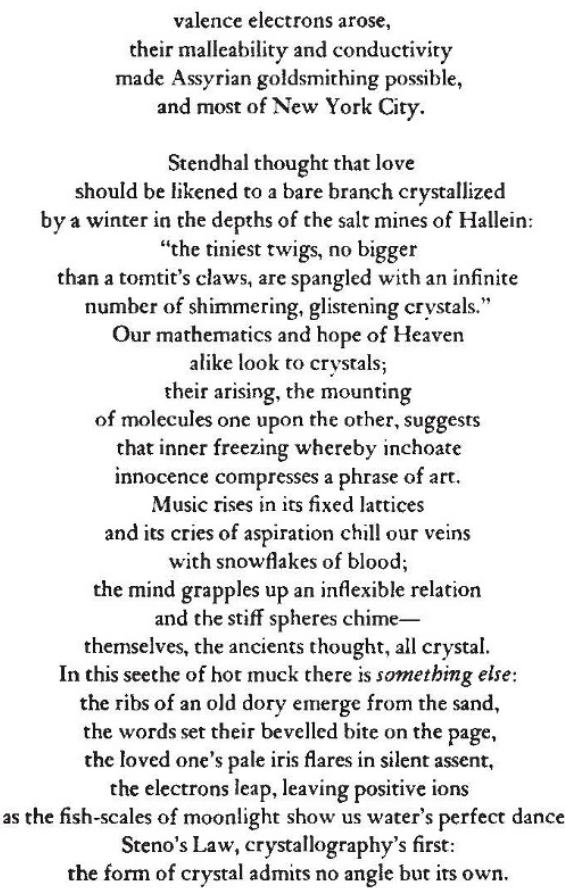

